\title{
Expression of NMDA-Receptor mRNA in the rat cochlea
}

\author{
Hiromichi Kuriyama ${ }^{a}$, Roger L. Albin ${ }^{b}$ and Richard A. Altschuler ${ }^{a}$ \\ ${ }^{a}$ Kresge Hearing Research Institute and ${ }^{b}$ Department of Neuroscience, University of Michigan, Ann Arbor, Michigan, USA
}

(Received 20 November 1992; Revision received 24 March 1993; Accepted 7 May 1993)

\begin{abstract}
While there is considerable evidence that an excitatory amino acid and excitatory amino acid receptors are involved in the synapse between inner hair cells and the auditory nerve, evidence for the specific involvement of the $N$-methyl- $D$-aspartate (NMDA) receptor is more ambiguous. With the cloning of the NMDA receptor, probes are now available that can determine in which neurons the receptor is being expressed. In situ hybridization histochemical techniques were therefore utilized to examine the expression of NMDA receptor messenger ribonucleic acid (mRNA) in the rat cochlea. Expression of NMDA receptor mRNA was seen in spiral ganglion cells. These results suggest that NMDA receptor is a component of excitatory amino acid synapses in the cochlea.
\end{abstract}

Excitatory amino acid; NMDA receptor; Cochlea; Spiral ganglion cells; In situ hybridization; Rat

\section{Introduction}

There is now considerable evidence suggesting that glutamate or a related excitatory amino acid (EAA) is the transmitter in cochlear hair cells (e.g., Altschuler et al., 1989; Bledsoe et al., 1988; Drescher et al., 1983; Eybalin and Pujol, 1983; Felix and Ehrenberger, 1985; Fex et al., 1985; Godfrey et al., 1976; Gulley et al., 1979; Schwartz and Ryan, 1986) and that it acts on excitatory amino acid receptors (Bledsoe et al., 1988 for review). While the evidence is strong that the $\alpha$-amino-3-hydroxy-5-methyl-4-isoxazole propionic acid (AMPA) receptor is involved in the inner hair cellauditory nerve synapse (Altschuler et al., 1991; Doi et al., 1992; Jenison and Bobbin, 1985; Jenison et al., 1986; Ryan et al., 1991a), there is pharmacological evidence both for (Ehrenberger and Felix, 1991; Puel et al., 1991) and against (Bledsoe et al., 1988; Bobbin et al., 1981; Bobbin and Ceasar, 1987; Fex and Martin, 1980; Jenison et al., 1986) involvement of $N$-methyl- $D$ aspartate (NMDA) receptors at this synapse. NMDA receptors are believed to be involved in many central nervous system (CNS) EAA synapses (Collingridge et al., 1988; Collingridge and Singer, 1990; Cotman and Iversen, 1987; Monaghan et al., 1989; Watkins et al., 1990). The NMDA receptor is not straight-forward to examine pharmacologically, since it is not always active. Magnesium $(\mathrm{Mg})$ ions block the action of the

Correspondence to: Richard A. Altschuler, Kresge Hearing Research Institute, The University of Michigan, 1301 E. Ann Street, Ann Arbor, MI 48109-0506, USA. Fax: + 1 (313) 764-0014.
NMDA receptor by filling the integral ion channel, unless removed as a result of post-synaptic changes, such as specific levels of depolarization. In the CNS, high frequency stimulation is often necessary to produce the level of post-synaptic depolarization to remove the $\mathrm{Mg}$ ion and 'activate' the NMDA receptor (Collingridge et al., 1988). Studies of inner hair cell synapses that have shown involvement of the NMDA receptor required repetitive neuronal depolarization for it to become active (Ehrenberger and Felix, 1991; Puel et al., 1991). In situ hybridization is a method which can determine if the mRNA producing specific proteins such as transmitters or receptors is present in a cell, providing a specific and sensitive method for examining if a neuron produces a specific protein. Recently, two sequences for the NMDA receptor have been reported in rat (Kumar et al., 1991; Moriyoshi et al., 1991), and each of them has different properties. The sequence from Moriyoshi et al. (1991), now termed NMDAR-1, encodes a protein with the electrophysiological and pharmacological properties of the NMDA receptor (Moriyoshi et al., 1991). The Kumar et al. (1991) sequence, which we will term NMDAR-K, is a non-homologous protein and may be a subunit of the NMDA receptor complex (Kumar et al., 1991), but is inactive by itself. Oligonucleotide probes against sequences from both NMDAR-1 and NMDAR-K were used to study expression of possible NMDA receptors in the rat cochlea using in situ hybridization histochemical techniques.

For the in situ hybridization of rat cochlea, no loss of mRNA was detected following the use of decalcification solutions at $4^{\circ} \mathrm{C}$ when paraformaldehyde was added to the EDTA solutions (Ryan et al,, 1991b) 


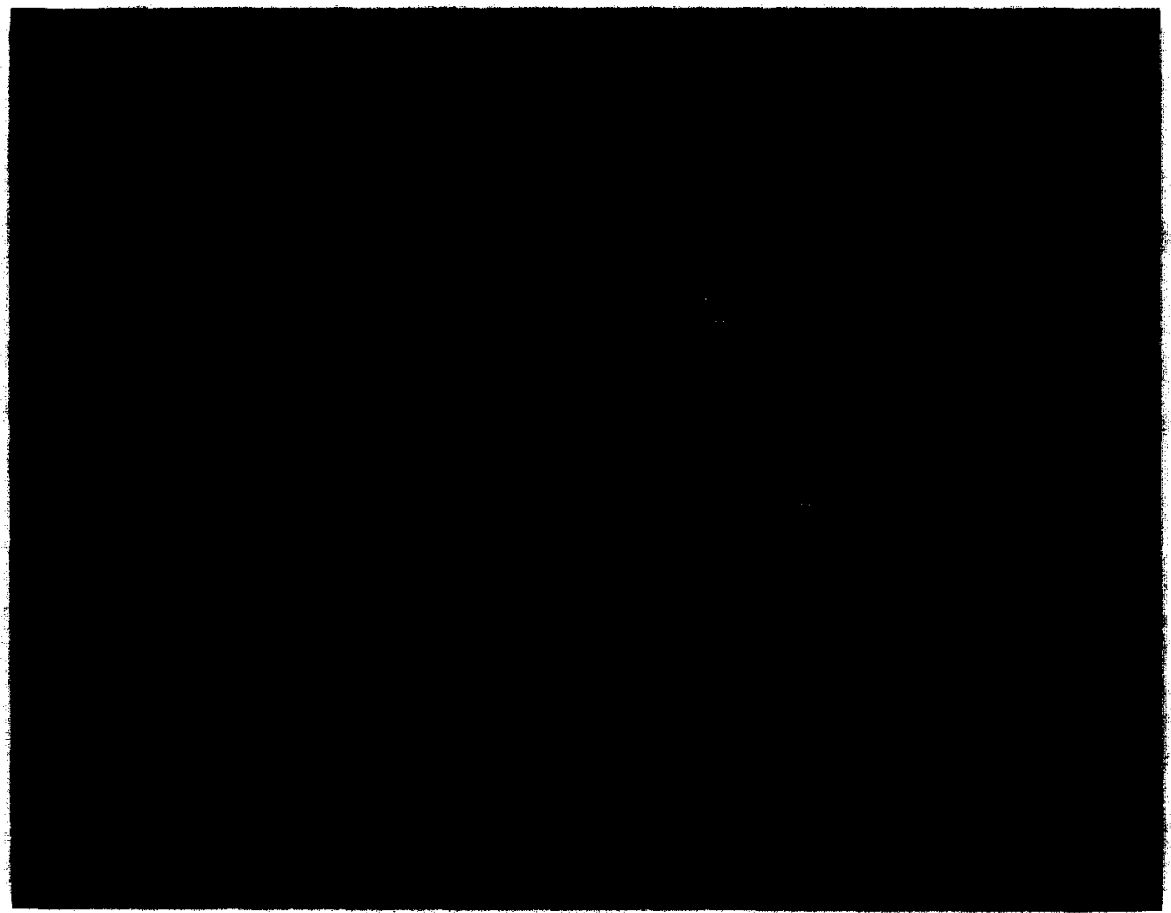

Fig. 1. Dark-field photomicrograph of a cryostat section through the second turn of a rat cochlea reacted with ${ }^{35}$ S-labeled probe to NMDAR-1, using in situ hybridization histochemical techniques. A high density of silver grains corresponding to expression of NMDAR-1 mRNA, is seen over spiral ganglion cells. $\mathrm{SGC}=$ Spiral ganglion cells; Scale bar $=25 \mu \mathrm{m}$.

\section{Materials and Methods}

Five male Sprague-Dawley rats weighing $150-200$ gm were heavily anesthetized with $17.5 \%$ Chloral hydrate $(0.2 \mathrm{ml} / 100 \mathrm{gm})$ and sacrificed by decapitation. Cochleae were removed from the temporal bone and received intrascalar fixation with $4 \%$ paraformaldchyde in $0.1 \mathrm{M}$ phosphate buffer (PB). Cochleae were then decalcified with $3 \%$ EDTA and $4 \%$ paraformaldehyde in $0.1 \mathrm{M} \mathrm{PB}$ at $4^{\circ} \mathrm{C}$ for 3-5 days and then rapidly frozen with liquid nitrogen. Frozen cochleae were sectioned $(15 \mu \mathrm{m})$ at $-20^{\circ} \mathrm{C}$, thawmounted on glass slides, and stored and frozen at $-70^{\circ} \mathrm{C}$ until hybridization. The in situ hybridization histochemical technique was carried out according to the methods of Arentzen et al. (1985) and Young et al. (1986). The oligonucleotide probes (each 45mer) used in this study were synthesized in an Applied Biosystems model DNA synthesizer and then purified using Hitachi high pressure liquid chromatography (ODS column chromatography). The probes were made of the antisense codons of Moriyoshi et al's sequence (2225-2269bp, NMDAR-1) and Kumar et al's sequence (1107-1151bp, NMDAR-K). Specificity of the probes was tested using a computer assisted homology search (Gen Bank R 68.0, June 1991, National Institutes of Health) against any sequences contained in the gene bank. Both probes had less than 35\% homology with any other known scquences.

Probes were endlabeled with $\alpha-{ }^{35} \mathrm{~S}$ dATP New England Nuclear (NEN) using a $3^{\prime}$ end labeling kit (NEN). Sections were post-fixed in $4 \%$ paraformaldehyde in $0.1 \mathrm{M}$ PB for 1 hour. Fixed tissues were rinsed three times for $5 \mathrm{~min}$ each in $0.1 \mathrm{M}$ phosphate buffered saline (PBS), washed sections were incubated in $0.25 \%$ acetic anhydride in $0.1 \mathrm{M}$ triethanolamine $0.9 \% \mathrm{NaCl}$ solution. After being dehydrated in graded ethanol and delipidized in chloroform, the sections were incubated with $100 \mu \mathrm{l}$ of hybridization buffer containing ${ }^{35} \mathrm{~S}$ labeled oligonucleotide $2 \times 10^{5}-4 \times 10^{5} \mathrm{cpm} / \mu \mathrm{l}, 10 \%$ dextran sulfate, Denhardt's solution, $0.1 \mathrm{M}$ dithiothreitol and $50 \%$ deionized formamide in a humid atmosphere overnight at $37^{\circ} \mathrm{C}$. The slides were washed in $2 \times$ Sodium Citrate; Sodium chloride (SSC) for $30 \mathrm{~min}$

Fig. 2. Photomicrographs of spiral ganglion cells in cryostat sections of rat cochlea reacted with ${ }^{35}$ S-labeled probe to NMDAR-1 using in situ hybridization histochemistry. 2a Bright-field photomicrograph of section reacted with probe to NMDAR-1 showing many silver grains over spiral ganglion cells, corresponding to expression of NMDAR-1 mRNA. scale bar $=10 \mu \mathrm{m}$. $2 \mathrm{~b}$ Confocal micrograph with five different focuses digitally combined to show many silver grains over spiral ganglion cells using probe to NMDAR-1. scale bar $=10 \mu \mathrm{m}$. $2 \mathrm{c}$ Bright-field photomicrograph of section reacted with ${ }^{35}$ S-labeled sense probe of NMDAR-1 mRNA as control. No significant labeling is seen over spiral ganglion cells; Scale bar $=10 \mu \mathrm{m}$. 

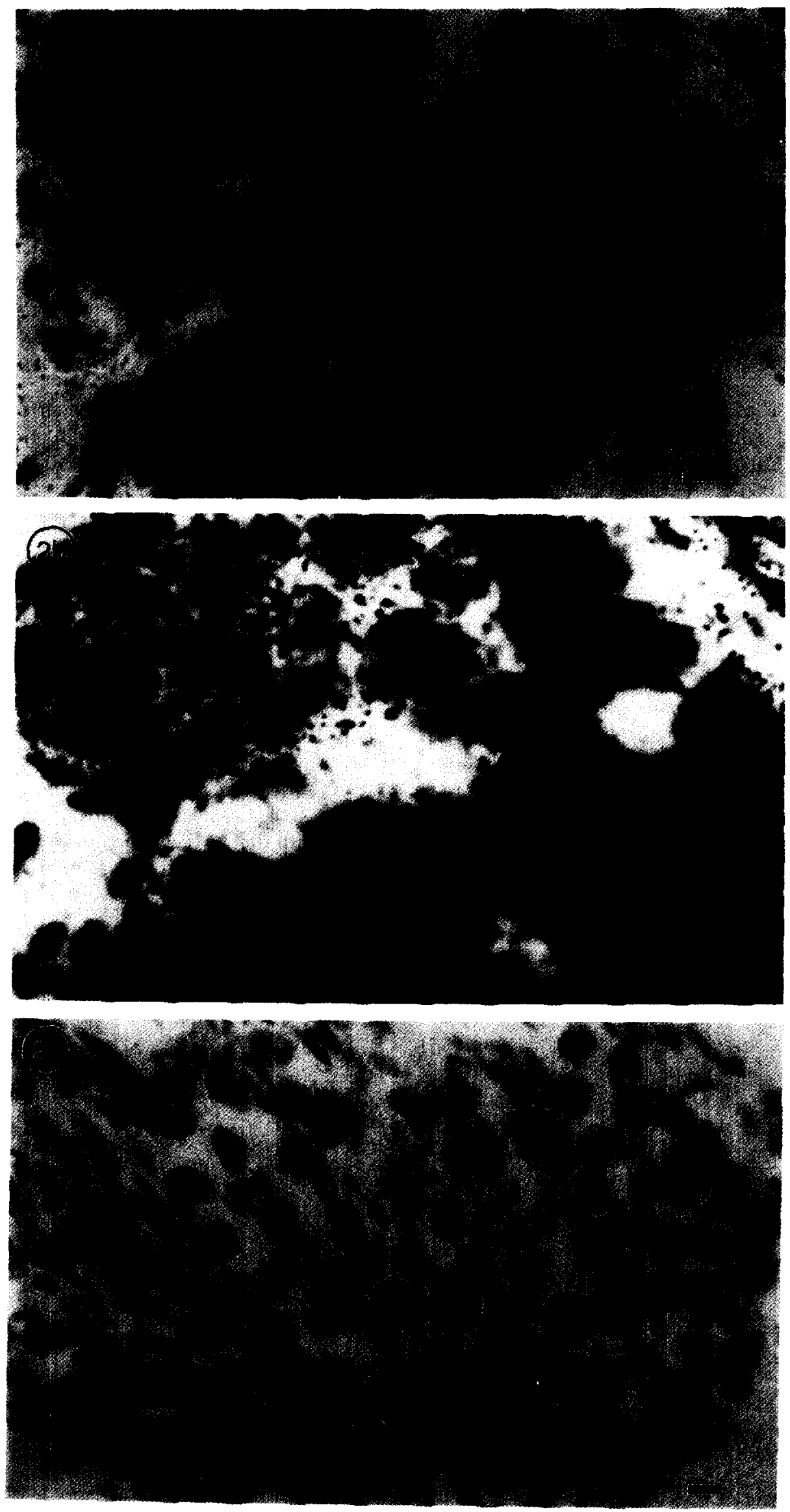
followed by washing in $1 \times$ SSC for $30 \mathrm{~min}$ and $0.5 \times$ $\mathrm{SSC}$ for $45 \mathrm{~min}$ at room temperature and for $60 \mathrm{~min}$ at $37^{\circ} \mathrm{C}$. For control, the specificity of the hybridization signals was checked by prehybridizing sections with pancreatic RNase A $(200 \mu \mathrm{g} / \mathrm{ml}$ Sigma $)$ in $10 \mathrm{mM}$ Tris- $\mathrm{HCl}, 0.5 \mathrm{M} \mathrm{NaCl}$ and hybridizing other sections with sense probes. To assess the specificity of the staining to specific cells the number of silver grains over spiral ganglion cells was compared to other regions including stria vascularis, spiral ligament, supporting cells and limbus using three rats. Counts of silver grains over areas of equivalent size in photomicrographs were made by three unbiased observers and results averaged.

The care and use of animals reported in this study was approved and supervised by the University of Michigan Unit on Laboratory Animal Medicine under NIDCD grants DC00078, 'Perception and Processing of Complex Signals', and DC00383, 'Amino Acid Transmitters in the Auditory Brain Stem'.

\section{Results}

\section{NMDAR-1}

A high density of silver grains was seen over spiral ganglion cells using the probe to NMDAR-1 (Figs. 1, $2 a, b)$. When this density was compared to other regions of the cochlea, the number of silver grains over spiral ganglion cells $(225 \pm 69$, indicated by mean \pm standard deviations $N=30$ cells) was more than an order of magnitude over the number of grains in other regions assessed $(14 \pm 7, N=30$ cells in spiral liga- ment, $4 \pm 3, N=30$ cells in stria vascularis, $8 \pm 6$, $N=30$ cells in supporting cells and $7 \pm 6, N=30$ cells in limbus). This provides evidence that NMDAR-1 mRNA is specifically expressed in the cochlea in spiral ganglion cells. Spiral ganglion cells without heavy labeling were only occasionally observed. While the majority of labeled spiral ganglion cells could be identified as type I, unlabeled neurons could not be differentiated as type II spiral ganglion cells. Increased numbers of silver grains were not seen over the organ of Corti. No significant labeling was seen over spiral ganglion cells in control sections (Fig. 2c).

\section{NMDAR-K}

No increase in the density of silver grains over spiral ganglion cells or any other specific region of the cochlea was observed using the NMDAR-K probe (Fig. 3).

\section{Discussion}

Intense expression of NMDAR-1 mRNA in spiral ganglion cells provides strong evidence that the NMDA receptor is a component of the inner hair cell - auditory nerve synapse. It is possible, however, that NMDAR-1 mRNA is expressed, but not translated, or that NMDA receptors are used presynaptically in auditory nerve synapses in the cochlear nucleus. When antibodies to the NMDA receptor become available, these can address the issue of synaptic placement, as we have done with the AMPA receptor in the cochlea. The lack of expression of NMDAR-K mRNA suggests that this subunit may not be involved in transmission at the

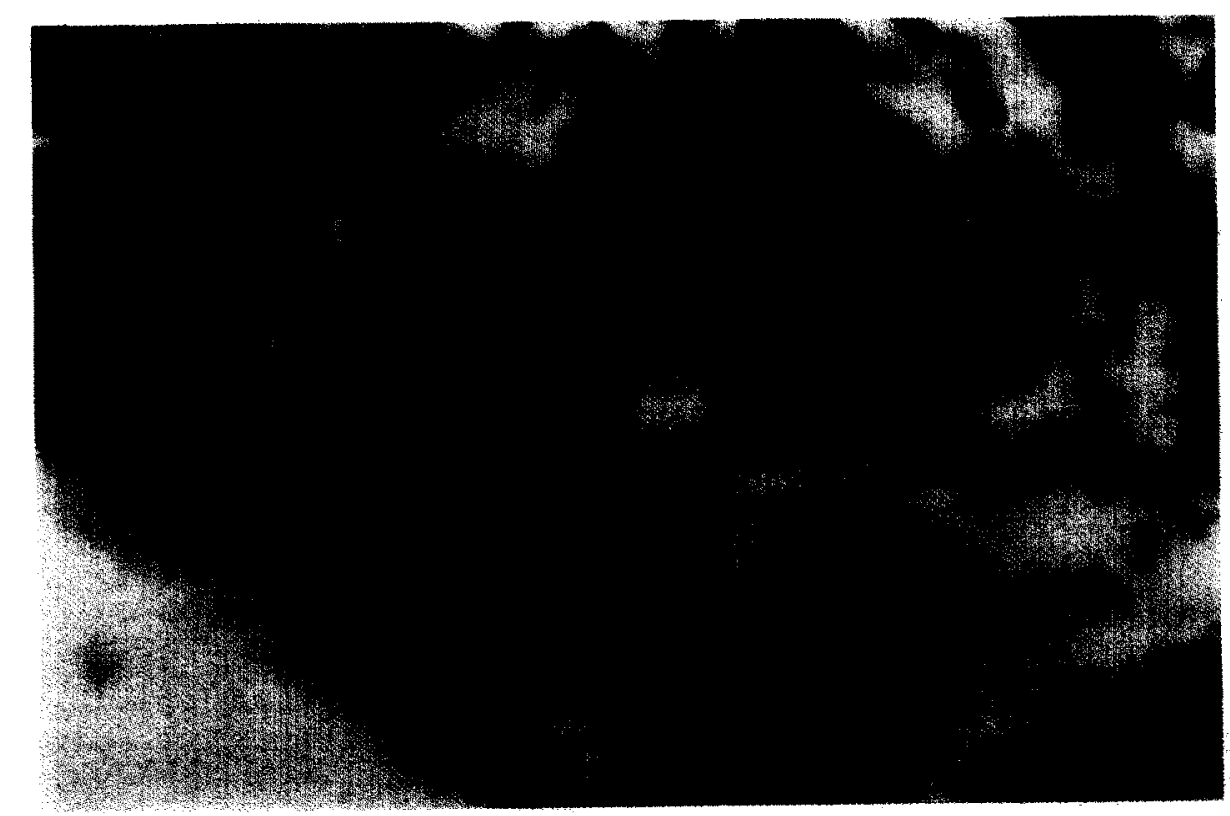

Fig. 3. Photomicrograph of spiral ganglion cells in cryostat sections of rat cochlea reacted with ${ }^{35}$ S-labeled probe to NMDAR-K using in situ hybridization histochemistry. No significant labeling is seen over spiral ganglion cells; Scale bar $=10 \mu \mathrm{m}$. 
inner hair cell - auditory nerve synapse. We have observed expression of both NMDAR-1 and NMDAR$K$ in neurons of the rat cochlear nuclei and superior olivary nuclei (Kuriyama et al., 1992).

Although expression of NMDA receptor mRNA was not seen in hair cells, the possibility that NMDA receptors have a pre-synaptic localization at the IHC synapses, as suggested by several groups (Ehrenberger and Felix, 1991; Starr and Sewell, 1991; Puel et al., 1991), cannot be ruled out and it might be due to difficulty in preserving the mRNA in cryostat sections of the cochlea or to very low levels of NMDA receptor mRNA in hair cells.

We have observed differential localization of different subunits of the AMPA receptor in the rat cochlea using immunohistochemical techniques. GluR $2 / 3$ and GluR4 were observed in the rat spiral ganglion cells, while GluR1 was not (Altschuler et al., 1991). Differential expression of AMPA receptors in the cochlea has also been observed with in situ hybridization (Ryan et al., 1991a) and PCR (Doi et al., 1992; Dresher et al., 1992). There is now evidence that there are multiple subunits of NMDA receptor as well (Kumar et al., 1991; Monyer et al., 1992; Moriyoshi et al., 1991), and future studies will be necessary to further define the NMDA receptor in the cochlea.

\section{Acknowledgment}

We would like to thank Drs. Sadao Shiosaka and Koji Sato, Department of Neuroanatomy, Biomedical Research Center, Osaka University, Japan, for their kind gift of NMDA receptor oligoprobes and helpful comments. We also thank Dr. Sharin Sakurai and Kevin Kaatz, Department of Neuroscience, University of Michigan, for their valuable assistance. This work was supported by NIDCD grants DC00383, DC00078 and NS19613.

\section{References}

Altschuler, R.A., Sheridan, C.E., Horn, J.W. and Wenthold, R.J. (1989) Immunocytochemical localization of glutamate immunoreactivity in the guinea pig cochlea. Hear. Res. 42, 167-174.

Altschuler, R.A., Hunter, C., Raphael, Y. and Wenthold, R.J. (1991) Immunocytochemical localization of AMPA receptor subunits in the rat cochlea. Soc. Neurol. Abstr. pp 1214.

Arentzen, R., Baldino, F., Davis, L.G., Jiggins, G.A., Lin, Y., Manning, R.W. and Wolfson, B. (1985) In situ hybridization of putative somatostatin mRNA within hypothalamus of the rat using synthetic oligonucleotide probes. J. Cell. Biochem. 27, 415-422.

Bledsoe, S.C., Bobbin, R.P. and Puel, J.L. (1988) Neurotransmission in the inner ear, In: A.F. Jahn and J.R. Santos-Sacchi (Eds.), Physiology of the Ear. Raven Press, NY, pp. 385-406.

Bobbin, R.P., Bledsoe, S.C. and Chihal, D.M. (1981) Effect of various excitatory amino acid antagonists on guinea pig cochlea potentials. Abstr. Assoc. Res. Otolaryngol. pp. 27.
Bobbin, R.P. and Ceasar, G. (1987) Kynurenic acid and gamma- $D$ glutamylaminomethylsulfonic acid suppresses the compund action potential of the auditory nerve. Hear. Res. $25,77-81$.

Collingridge, G.L., Herron, C.E. and Lester, R.A.J. (1988) Frequency-dependent $N$-methyl- $D$-aspartate receptor mediated synaptic transmission in the rat hippocampus. J. Physiol. (Lond.) $399,301-312$.

Collingridge, G.L. and Singer, W. (1990) Excitatory amino acid receptor and synaptic plasticity. Trends Pharmacol. Sci. 11, 290296.

Cotman, C.W. and Iversen, L.L. (1987) Excitatory amino acids in the brain focus on NMDA-receptor. Trends Neurosci. 10, 263-265.

Doi, K., Yokotani, N., Hunter, C., Wada, K. and Wenthold, R.J. (1992) DNA amplification of subunits of the AMPA selective glutamate receptor family of the rat and guinea pig cochlea. Abstr. Assoc. Res. Otolaryngol. pp. 19.

Drescher, M.J., Drescher, D.G. and Medina, J.E. (1983) Effect of sound stimulation at several levels on concentrations of primary amines, including neurotransmitter candidates in perilymph of the guinea pig inner ear. J. Neurochem. 41, 309-320.

Drescher, G.G., Wilcox, E.R. and Fex, J. (1992) Molecular cloning of a glutamate receptor sequence from the mouse cochlea. Abstr. Assoc. Res. Otolaryngol. pp. 10.

Fhrenherger, $K$. and Felix, D. (1991) Glutamate receptors in afferent cochlear neurotransmission in guinea pigs. Hear. Res. 52, 73-80.

Eybalin, M. and Pujol, R. (1983) A radioautographic study of $\left[{ }^{3} \mathrm{H}\right] \mathrm{L}$ glutamate and $\left[{ }^{3} \mathrm{H}\right] \mathrm{L}$-glutamine uptake in the guinea pig cochlea. Neuroscience 9, 863-872.

Felix, D, and Ehrenberger, K. (1985) The action of putative neurotransmitter substances in the mammalian labyrinth. In: D.G. Drescher (Ed.), Auditory Biochemistry, Charles C Thomas, Springfield, IL, pp. 68-79.

Fex, J. and Martin, M.R. (1980) Lack of effect of DL-alphaaminoadipate, an excitatory amino acid antagonist on cat auditory nerve response to sound. Neuropharmacology 19, 809-811.

Fex, J., Kachar, B., Ruibio, J.A., Parakkal, M.H. and Altschuler, R.A. (1985) Glutaminase-like immunoreactivity in the guinea pig cochlea. Hear. Res. 17, 101-113.

Godfrey, D.A., Carter, J.A., Berger, S.J, and Matshinsky, F.M. (1976) Levels of putative transmitter amino acids in the guinea pig cochlea. J. Histochem. Cytochem. 24, 468-472.

Gulley, R.L., Fex, J. and Wenthold, R.J. (1979) Uptake of putative neurotransmitters in the organ of Corti. Acta Otolaryngol. (Stockh). 88, 177-182.

Jenison, G.L. and Bobbin, R.P. (1985) Quisqulate excites spiral ganglion neurons of guinea pig. Hear. Res. 20, 261-265.

Jenison, G.L., Winbery, S. and Bobbin, R.P. (1986) Comparative actions of quisqulate and $N$-methyl- $D$-aspartame, excitatory amino acid agonists, on guinea pig cochlea. Comp. Biochem. Physiol. 84, 385-389.

Kumar, K.N., Tilakarate, N., Johnson, P.S., Allen, A.E. and Michaelis, E.K. (1991) Cloning of cDNA for the glutamate-binding subunit of an NMDA receptor complex. Nature 354, 70-73.

Kuriyama, H., Albin, R.L., Shiosaka, S. and Altschuler, R.A. (1992) Expression of NMDA-Receptor mRNA in the rat auditory system. Soc. Neuro. Abstr. pp. 1192.

Monaghan, D.T., Bridges, R.J. and Cotman, C.W. (1989) The excitatory amino acid receptor: their classes, pharmacology and distinct properties in the function of the central nervous system. Rev. Pharmacol. Toxicol. 29, 365-402.

Monyer, H., Sprengel, R., Schoepter, R., Herb, A., Higuch, M., Lomel, H., Burnashev, N., Sakmann, B. and Seeburg, P,H. (1992) Heteromeric NMDA-Receptor; Molecular and functional distinction of subtypes. Science 256, 1217-1221.

Moriyoshi, K., Masu, M., Ishii, T., Shigemoto, R. Mizuno, N. and Nakanishi, S. (1991) Molecular cloning and characterization of the rat NMDA receptor. Nature 354, 31-37. 
Puel, J.L., Ladrech, S., Chabert, R., Pujol, R. and Eybalin, M. (1991) Electrophysiological evidence for the presence of NMDA receptors in the guinea pig cochlea. Hear. Res. 51, 255-269.

Ryan, A.F., Brumm, D. and Kraft, M. (1991a) Occurrence and distribution of non-NMDA glutamate receptor $m R N A$ in the cochlea. Neuroreport 2, 643-646.

Ryan, A.F., Watts, A.G. and Simmons, D.M. (1991b) Preservation of mRNA during in situ hybridization in the cochlea. Hear. Res. 56, $148-152$.

Schwartz, I.R. and Ryan, A.F. (1986) Uptake of amino acids in the gerbil cochlea. In: R.A. Altschuler, D.W. Hoffman and R.P. Bobbin. (Eds.), Neurobiology of Hearing; The Cochlea, Raven Press, NY pp. 173-190.
Starr, P.A. and Sewell, W.F. (1991) Neurotransmitter from hair cells and its blockade by glutamate receptor antagonists. Hear. Res. $52,23-41$.

Watkins, J.C., Krogasgaard-Larsen, P. and Horore, T. (1990) Structure-activity relationships in the development of excitatory amino acid receptor agonists and competitive antagonist. Trends Pharmacol. Sci. 11, 25-30.

Young, W.S. III., Bonner, T.I. and Brann, M.R. (1986) Mesencephalic dopamine neurons regulate the expression of neuropeptide mRNA in the rat forebrain. Proc. Natl. Acad. Sci. USA 83, 9287-9831. 